\title{
Research on Strengthening and Improving the Construction of the Theme Website of Ideological and Political Education in Colleges and Universities of Jilin Province
}

\author{
Lujun Lv \\ Jilin Agricultural Science and Technology University \\ Jilin, China 132101
}

\begin{abstract}
This paper expounds the real problem of the construction of the theme website of ideological and political education in colleges and universities, analyzes the causes of its formation, and analyzes the existing problems of ideological and political education in colleges and universities in Jilin Province from the aspects of network consciousness, ideology and normative network moral, strengthen the network supervision, improve the attractiveness of ideological and political education, and so on, put forward to strengthen and improve the ideological and political education in Jilin Province, the theme of the construction of the website.
\end{abstract}

Keywords—theme site; problems; countermeasure

\section{INTRODUCTION}

As a large number of people in the province of Jilin Province, a wide range of disciplines, responsible for the country to train all kinds of professionals at all levels of the task. Century-old, education-oriented, moral first In the new situation, to strengthen and improve the ideological and political education of college students has been mentioned unprecedented height. In December 2016, Xi Jinping general secretary in the national ideological and political education work stressed that: do a good job of ideological and political work in colleges and universities, due to the trend of the situation, because of the times into the new situation. In the Internet has become a way of life today, whether it can be a powerful way to occupy cyberspace, attracting young college students' attention is a serious test of college educators. [1] Up to now, more than $96 \%$ of Jilin colleges and universities have established a special ideological and political education website, college network ideological and political education work has entered a comprehensive development stage. But at the same time also faced with many problems, need to be resolved.

This is Jilin Province Department of Education "thirteen five" social science research project "Jilin province ideological and political education theme website construction status quo and countermeasures" (subject contract number: JJKH20170352SK)

\section{The MAIN PROBLEMS IN THE CONSTRUCTION OF THE SUBJECT WeBsite OF IDEOLOGICAL AND POLITICAL EDUCATION IN JILIN PROVINCE}

The first is network construction. With the advent of the Internet information age, the rapid popularization of the Internet, multimedia teaching has been popular in the university classroom, the status of traditional teaching methods of college teachers is weakened, the traditional ideological and political education model also encountered challenges. In the face of this sudden change in education, although colleges and universities in Jilin Province has been continuing to carry out ideological and political education network, but the ideological and political education on the network is not enough depth, and in practice still need to strengthen. Some colleges and universities in the campus LAN, from web production to web content are unsatisfactory, in the form of. Some colleges and universities in Jilin Province, the problem of backward network construction, mainly due to the importance of the network in ideological and political education did not get enough attention. Some colleges and universities simply understand the Internet as a modern communication and communication of information tools, and did not see in this era of information, information networks for the University to carry out the positive significance of ideological and political education. These are simple to the network as a simple communication and communication tools of colleges and universities, naturally will not pay attention to the network and related hardware facilities, the general lack of investment; even with the necessary hardware facilities, but also the lack of routine maintenance, Construction, a great waste of network resources. Network as the basic carrier of ideological and political education network, in the development of the backward directly lead to the lack of ideological and political education network

The second is the lack of subjectivity of ideological and political education in network. The subjectivity of ideological and political education refers to the autonomy, initiative and creativity embodied in the practice of ideological and political education. The main body of the 
ideological and political education in colleges and universities in Jilin province includes the ideological and political education workers, [2] the subject is the college students, their subjectivity to a large extent affect the effectiveness of ideological and political education network. At present, the main body of ideological and political education in Jilin Province is still missing, manifested as: ideological and political education workers lack of innovation; responsibility and career concept can't meet the status quo; scientific theory and network knowledge can't meet the real needs; The lack of targeted training for students. Students in the network to select information when the quality is not high; the main activities on the network or friends, chat, online shopping, online games, listening to music, very few students take the initiative to use the network to carry out creative activities.

The main reason of the lack of subjectivity of ideological and political education in colleges and universities in Jilin Province is the influence of real social environment. With the rapid integration of the world and the rapid development of the network, people's value orientation is becoming more diversified, and the value of identity and spiritual pursuit is weakened. People's ideological and political education workers in the social status, material treatment have not been given enough attention to reduce the professional attraction and professional value of the sense of identity; the second is the traditional Chinese education concepts and ideas Bound. Chinese traditional culture too much emphasis on the authority of teachers, strictly distinguish between the status of teachers and college students, restricting the college students to play the subjectivity. The Chinese nation promote behave, emphasizing the effect of collective education, can't mobilize the ideological and political education workers and college students enthusiasm and initiative, but also restricts the subject of play.

The third is some College Students' Network Moral Autonomy Lack and Legal Awareness. Some college students in addition to the Internet published personal remarks, but also online insult to abuse others, the privacy of others on the network spread, to vent their dissatisfaction with the community or others, free to spread some bad information caused by social tongue to do some Unethical and illegal things. In the network of such a problem, because the network in the netizens themselves responsible for their own, their own master, own management of their own, so "network society" and the reality of social morality compared to showing a more Less dependency, more autonomy. Due to the virtuality of the network identity, coupled with the lack of network moral autonomy and the lack of legal consciousness of some college students, it is wrong to think that they can express their personal views on the Internet, and that some of the acts and actions that have violated the law can be exempted from Legal sanctions, this burning morality has led to the occurrence of some cybercrime. [3] These students can not improve their own quality, can't correctly handle the negative impact of the network students, so that colleges and universities to effectively improve the effectiveness of ideological and political education network facing a greater test.
Fourth, the way of education is out of the real needs of college students. College students energetic, quick thinking, is the new generation, the new things have a strong curiosity and desire to pursue. Faced with such an education group, some colleges and universities are still using the traditional ideological and political education teaching model, the effect is very satisfactory. Although some colleges and universities have adopted the network as the media of ideological and political education, but not in-depth study of the characteristics of this group of college students, the university's educational foundation, acceptance and life characteristics of a specific analysis, which can't make full use of network resources to bring us Resource advantages, such as the school special website from the web to the content is very mechanical and single, mechanical copy of the ideological and political education materials, can't reflect the teaching characteristics of colleges and universities and research results. At present, the construction of ideological and political education network of college students in Jilin Province is similar, the characteristics are not obvious, and the management emphasizes the division of labor, lack of cooperation consciousness. According to the survey, few colleges and universities have introduced and implemented the management mechanism of the ideological and political education network of college students, and the system of responsibility and management in the management mechanism of most colleges and universities has not been implemented [4]. As the colleges and universities have their own secondary sites, they pay more attention to reflect the work of the basic functions of the unit and so on, so as to the ideological and political construction of college students, the construction of spiritual civilization, such as the proportion of small involved, resulting in these work also can't get very well implemented. Under the current situation of the operation of the mechanism, the use of the network to carry out ideological and political education of college students is difficult to achieve the desired results.

Fifth, educational content is not attractive. Most colleges and universities in Jilin Province do not make full use of network resources in ideological and political education. The content of network ideological and political education is mainly to copy books, High, the ideological and political education of college students is not obvious, but can't timely and accurate guidance and standardize the ideological and political ideas of college students. Some colleges and universities educators lack the educational experience and solid ideological and political education theory foundation, just simply imparts the book knowledge, can't be close to the student psychology, the university ideological and political education plays a substantive role, reduces the network ideological and political education Effectiveness. According to the survey data show that more than $90 \%$ of the students surveyed said that all kinds of sites on ideological and political education are not creative, web production is not refined; more than $50 \%$ of students believe that only in the examination or class After the job needs, will take the initiative to enter the site; that usually only see to think of this site students accounted for $20 \%$ of the total number of investigations. 
The sixth is the lack of system protection of network regulation. Due to the network is virtual, spread the multidirectional, coupled with the network media audience object set a variety of roles, they are both the recipient of information, but also the information publishers and communicators, resulting in regulatory methods can't use the traditional media supervision methods adopted by the way, in the technical, operational line on the network regulation also put forward higher requirements. Compared with the rapid development of China's network, network supervision and network management-related laws, regulations and systems are not perfect, there is lag, resulting in the lack of network regulation and regulatory support. Therefore, in such a large environment, Jilin Province prevails the lack of network supervision system of the phenomenon. The information on the campus network is not good, which is filled with some bad information, to the formation of a new world view of the students have a negative impact, the impact of their legal and moral values, affecting their physical and mental health, social Development brings hidden dangers. Therefore, how to manage the problems in the development of the network, strengthen the network supervision, to the students a clean and free virtual space has become a serious problem facing now.

\section{TO STRENGTHEN THE IDEOLOGICAL AND POLITICAL EduCATION IN JiLin PROVINCE, THE THEME OF THE CONSTRUCTION SITE COUNTERMEASURES}

With the continuous development of Internet technology, especially in the past decade of leaps and bounds, the network society has been intertwined with the real world and increasingly close, the network culture becomes more and more complex. The ideological and political education of college students is becoming an important field of ideological and political education. Therefore, it is necessary to strengthen the development of ideological and political education website in Jilin province.

First, it should pay attention to the role of the network in ideological and political education. Colleges and universities called China's talent pool, is the future of the motherland, is to achieve the great hope of the Chinese nation's great renaissance. With the continuous development of the world economy and science and technology, the world has developed into a "global village", the network with its fastness, diversity and put the characteristics of college students to provide a world understanding of society to understand the broad platform. But the network has the hidden nature of the information on the network is also good and bad, some negative information impact of contemporary college students' outlook on life, values and morality. New forms and tasks, the ideological and political education of colleges and universities put forward new and higher requirements, the need for colleges and universities and even the whole society to put more attention and energy. However, through visiting the campus network of colleges and universities in Jilin Province, it is found that colleges and universities in Jilin Province lack sufficient attention to the ideological and political education, and do not realize the influence of the new mass media represented by the Internet as a college student. College students have not yet formed a mature world outlook, outlook on life and values, the lack of network information discrimination, judgment and resistance to bad information. Therefore, the colleges and universities in Jilin Province must adapt to the changes of the educational environment in time, raise the awareness of the importance of the ideological and political education on the network, open up and occupy the ideological and political education positions, speed up the ideological and political education related network hardware and software construction, promote advanced culture and The main theme of the times, the release of positive energy to help college students resist all kinds of vulgar information, reactionary information, the Western cultural infiltration and ideological invasion.

The second is to enhance the subjective consciousness of the instructor and the instructor. Ideological and political education workers to establish the concept of subjectivity, clear their role in positioning, grasp their career direction; constantly improve themselves and improve the overall quality, in addition to should have a solid theoretical foundation of ideological and political education, should have a broad vision, in the To accept the advanced educational ideas and the latest national political fine, can have a certain logical methodology and political sensitivity, and gradually build a sound value system, so as to be able to correctly guide the students, to enhance their ideological and political quality. In addition, the network of ideological and political education and traditional ideological and political education, in the ways, ideas, carriers, skills, etc. have their own different characteristics, which require college ideological and political education workers can familiar with the Internet knowledge, timely grasp The development of the Internet's new developments, and its rapid integration into the daily teaching. In the ideological and political education network, we should emphasize the interaction between teachers and students on the basis of equality; pay attention to the emotional communication with the students, rather than simply impart knowledge, good emotional communication will achieve better educational results. In addition, in the process of ideological and political education, we should fully respect the subject consciousness of college students. To enhance the independence and autonomy of college students' participation in network practice activities, to attach importance to cultivating students' self-education ability while accumulating knowledge; to guide college students to improve their ability to control the network, to cultivate students' self-discipline behavior, to improve network ideological and political education Effectiveness[1].

The third is to enhance the quality of college students' moral and legal literacy. College students are the future builders and successors of the cause of socialism in China. It is an important force to build a well-off society in an allround way and realize the great dream of reviving the Chinese dream. As colleges and universities that cultivate high-quality talents, colleges and universities must break the simple, Compulsory legal irrigation education model, the use of a variety of educational methods, for college students lack of legal theory knowledge, common knowledge of the current situation of fuzzy problems such as the status quo, to 
enable college students are willing to accept the form of legal education to help them establish legal beliefs, Literacy [5]. Jilin Province, the colleges and universities have developed a school discipline, these provisions are a strong guarantee for the normal operation of the school. The collective concept of contemporary college students is weak, the sense of self discipline is not strong, it is easy to violate the rules and regulations of the school, so it is necessary to increase the education of college students' common disciplinary action. For the fresh men, the beginning of the school will let it be familiar with the various rules and regulations within the school, you can through the website, class, school newspaper, learning manual and other promotional tools to promote and explain, to enhance students to observe school discipline

The fourth is to strengthen network supervision and related legal system. In the real world only rely on the power of morality to ensure the normal operation of society is impossible, we must rely on the law to support the development and progress of society, in the online world also need laws and regulations to regulate it[6]. Therefore, the relevant functional departments in the province is to ensure that the ideological and political education of colleges and universities to provide legal and legal protection. In view of the current network of bad information, the State Ministry of Public Security, Ministry of Industry and Information Technology and the State Council Information Office and other relevant departments have introduced a number of laws and regulations, these legislation on the current network problems have made the corresponding constraints Some basic norms, colleges and universities can be based on these laws and regulations on the actual work of the problems to be dealt With the further development of the network, all kinds of problems will follow, therefore, the need for social and university efforts together, the establishment of the corresponding mechanism to solve the loopholes in network supervision loopholes for college students to create a good platform for ideological and political education.

\section{CONCLUSION}

The Internet is a significant technological progress made by mankind in twentieth Century, and its emergence and development have had a profound impact on the whole society. As the most prominent development in front of "network" in Chinese society, colleges have been greatly influenced on College Students' life, learning, thinking and belief. In this case, the traditional ideological and political education is facing severe challenges and great opportunities. It is a new subject which must be studied in the ideological and political education in modern colleges. It is necessary to pay attention to the changes of the network age with the development vision, foresee and analyze the influence of the network on the college students. Based on this understanding, this article on the current situation of Jilin Province colleges Network Ideological and political education to undertake analysis focuses on the face of Jilin Province colleges Network Ideological and political education problems and the causes of the problems which has the use of Ideological and political education theory in the computer network under the background of rapid development from the ideological and political education practice. It systematically analyzes the current situation, the ideological and political education in Colleges and universities in Jilin province network problems, and put forward how to strengthen and improve the ideological and political education in universities and colleges fundamental countermeasures of political education network in Jilin province. This paper tries to find out the breakthrough point and puts forward the management reform and innovation measures of the construction of Ideological and political education in Colleges and universities, so as to build a new management strategy of the ideological and political education in Colleges and universities which conforms to the development of the times.

\section{REFERENCES}

[1] Zhang Yue Long. Reflections on Improving the Actual Effect of Ideological and Political Education on the Internet[J]. Journal of Agricultural University of Hebei, 2010 (06)

[2] Hu Shuxiang, Gao Yu. Network ideological and political education research status of large data analysis and thinking $[\mathrm{J}]$. Journal of ideological and theoretical education. 2016 (07)

[3] Feng Gang. innovation network ideological and political education of some thinking $[\mathrm{J}]$. School party building and ideological education. 2014 (05)

[4] Luo Yu-ting, Wei Qiang. On the ideological and political education of college students network culture discourse right $[\mathrm{J}]$. Teaching and research. 2012 (10)

[5] Hu Hongxia. Investigation of Ideological and political education website construction in Beijing University. [J]. ideological and political education research. 2007 (05)

[6] Qiao Xiangping, Chen Yanfei. New exploration of Ideological and political education of college students $[\mathrm{J}]$. Hunan social sciences. 2007 (01) 